\title{
INTEMPERISMO E MORFOGÉNESE NO PLANALTO DE CAMPOS DO JORDÃO (SP)
}

\author{
MAY CHRISTINE MODENESI*
}

\begin{abstract}
Weathering phenomena on the Campos do Jordão Plateau have been studied from a geomorphological point of view. The geochemical type of evolution and degree of weathering were analysed in order to show their relationship to geomorphic units and morphogenetic dynamics.

Soils, elluvium and sedimentary deposits are highly weathered and consist mainly of quartz, gibbsite and kaolinite. Aluminous vermiculite may occur in incipiently weathered granite and in some soils.

Correlations between the degree of weathering of surficial materials and the geomorphic units are more evident in weathered rock than in soils.

In the highest areas of the plateau gibbsite is the most important secondary mineral and bauxite is common. At lower topographic levels kaolinite prevails. Two weathering processes, alitization and monossialitization are thus defined and may be interpreted as different stages in a general alitic weathering trend.

In some hillsiope deposits, the degree and sequence of weathering is frequently related to downslope movement processes, rather than to the still incipient pedogenetic action. The superposition of colors, frequent in hillslope surficial materials, reflects two opposing pedogeochemical trends, the more ancient being ferralitic and the more recent tending towards podzolization.

The identification of past ferralitic weathering phenomena on the Campos do Jordão Plateau allows the correlation of the "superfície dos campos" (Campos Surface) to degradational processes active at lower altitudes prior to the uplift of the plateau to its present level and the consequent modification of climatic characteristics.
\end{abstract}

INTRODUÇÃo As alteraç̃es estão estreitamente relacionadas à dinâmica geomorfológica e são a um só tempo reflexo e motor da morfogênese. $O$ tipo de alteraçăo das formaçðes superficiais e seu grau de intemperismo refletem as condiçðes do meio e a intensidade da evoluçăo.

Tais premissas evidenciam a importância dos estudos de alteração em geomorfologia fornecendo, como assinalou Tricart (1965), elementos para o estabelecimento de correlaçð̃es geomorfológicas.

Numa abordagem espacial dos fenômenos de intemperismo no planalto de Campos do Jordão, esta pesquisa procura reconhecer variaçðes do intemperismo relacionadas à morfogênese.

Situado na porção oriental do Planalto Atlântico (Fig. 1), o planalto de Campos do Jordåo constitui a superficie cimeira o "teto principal dos planaltos em bloco do Brasil de Sudeste" (Ab'Saber e Bernardes, 1958) alçado no Terciário Superior, nos últimos eventos da Reativação Waldeniana (Almeida, 1976), por falhamentos normais guiados por antigas falhas transcorrentes (PréCambriano/Cambro-Ordoviciano) e pelo traço das juntas e da foliação (Hasui et alii, 1977). Seus topos elevam-se a 1.950-1.952 m (pico do Diamante e morro de Itapeva) e 2.029-2.050 m (Alto do Cerco e áreas próximas) na borda do planalto, onde podem ser reconhecidos indícios da "superficie dos altos campos" (De Martonne, 1940). Para o interior, fragmenta-se em serras

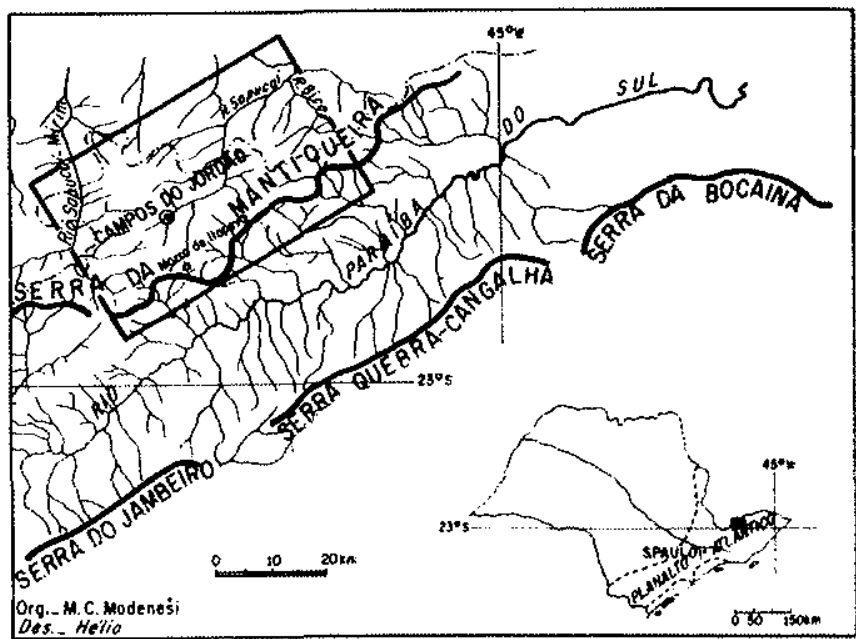

Figura 1 - Mapa de localização do planalto de Campos do Jordão

não muito extensas e picos, com altitudes de até 1.850-1.870 m (Pedra da Chita e Serra do Baú).

A superfície dos campos foi considerada por Freitas (1951) e Almeida $(1951,1964)$ como resultado de deformação oligocênica, acentuada no Plioceno, da "superficie do Japi"' (Almeida, 1976). O levantamento desta superfície paleógena e seu retrabalhamento quaterná-

* Estagiária junto ao Instituto de Geografia, USP, e bolsista da Fundaçao de Amparo à Pesquisa do Estado de São Paulo (FAPESP) Instituto de Geografia, USP, Cidade Universitária Armando de Sales Oliveira, caixa postal 20715, CEP 05508 - São Paulo - SP 
rio, sob climas de altitude, originaram um sistema de paisagem anômalo em regiăo tropical. Dotado de marcante individualidade climática, com formações superficiais e vegetação típica, caracteriza-se como um enclave de altitude no "domínio morfoclimático dos mares de morros" definido por Ab'Saber (1966, 1970, 1973).

O planalto de Campos do Jordå (Fig. 1) compreende o trecho da Mantiqueira entre os rios Sapucaím Mirim e das Bicas, limitado a sudeste pela escarpa da serra e a noroeste pelo alinhamento das serras de Água Limpa, de Pouso Frio e da Coimbra. A borda do planalto corresponde aproximadamente a falha de Jundiuvira (Hasui et alii, 1977). O alinhamento noroeste foi citado por Almeida (1964) como um provável limite tectônico do planalto. É nesta área, nos campos do Jordå, do Serrano, dos Nogueiras e de São Francisco, que a paisagem dos "altos campos" é mais típica.

Tais limites coincidem com aqueles considerados por Almeida (1964) em sua divisão morfológica do Estado de Såo Paulo. Os citados por Hasui et alii (1977), numa compartimentação puramente tectônica, transcendem a esses.

De acordo com o mapeamento efetuado pelo IPT (1978), predominam no planalto migmatitos e ectinitos do Grupo Açungui e rochas granitóides associadas (PréCambriano Superior). Ocorrem ainda migmatitos do Grupo Paraíba (Pré-Cambriano Médio).

Nos campos do Jordão e de São Francisco, entre a escarpa da Mantiqueira e o alto vale do Sapucaí-Guaçu, predominam rochas migmatíticas (estromatitos heterogêneos e homogêneos) do Grupo Açungui e granitóides associadas. Ocorrem ainda xistos, quartzitos e metaconglomerados.

A caracterização mineralógica dos estromatitos homogêneos e granitóides, aos quais se restringiu o presente estudo da alteração, é feita a seguir com base na descrição das unidades do mapeamento do IPT.

Migmatitos estromatíticos são caracterizados pela alternância de bandas de neossoma e de paleossoma feldspatizado ou intato. Nos estromatitos homogêneos, o paleossoma é geralmente de natureza gnáissica, ocasionalmente formado por xistos feldspatizados com teores variados de biotita. Os minerais essenciais (quartzo e biotita) e os acessórios (epídoto, apatita, opacos, clorita, turmalina, granada, zircão, hornblenda, sillimanita, alanita e muscovita) são os mesmos dos estromatitos heterogêneos com adição dos feldspatos, muito microclímnio e algum plagioclásio. O neossoma é granítico e às vezes aplítico, constituído essencialmente por quartzo, microclínio, algum plagioclásio e biotita. Esses estromatitos apresentam caráter oftalmítico generalizado. Localmente, porfiroblastos de feldspato, de seção lenticular, ovalada ou retangular, em número e tamanho variados (de milimétricos a decimétricos), chegam a mascarar a estrutura estromatítica. Podem ocorrer veios quartzofeldspáticos discordantes.

Os granitos constituem corpos intrusivos, pelo menos parcialmente. Seus minerais essenciais são quartzo, microclínio e plagioclásio. Os acessórios, biotita, muscovita, apatita, zircão, minerais opacos, titanita e alanita. Såo secundários sericita, epidoto, clorita e carbonatos. Apresentam caráter porfíroblástico marcado, com ocorrência de cristais de microclínio e plagioclásio de di- mensðes e formas semelhantes à dos estromatitos homogêneos.

No planalto de Campos do Jordăo (Estaçăo Meteorologica do DAEE, Vila Capivari), a temperatura média anual é de $14,3^{\circ} \mathrm{C}$ (período $1973 / 1978$ ). Janeiro e principalmente fevereiro são os meses mais quentes $(17,5 \mathrm{e}$ $17,3^{\circ} \mathrm{C}$, respectivamente) com temperaturas máximas de até $30^{\circ} \mathrm{C}$. Junho e julho, os meses mais frios $(10,9 \mathrm{e}$ $10,8^{\circ} \mathrm{C}$ ), com mínimas de $-3,2^{\circ} \mathrm{C}$. A ocorrência de geadas é comum de maio a agosto.

A pluviosidade varia muito, com totais anuais (Posto Pluviométrico D2-1, DAEE, Vila Capivari, período 1959/1976) entre 1.205 e $2.298 \mathrm{~mm}$. A distribuição das chuvas, durante o ano, mostra uma concentraçăo superior a $80 \%$ de outubro a março e um período relativamente seco de outono e inverno. Entretanto, um balanço hídrico sem deficiência garante suficiente umidade no solo o ano inteiro. Na porçåo mais elevada do planalto, a influência orográfica provoca diminuição da temperatura e aumento das precipitações. A estação seca é pouco nítida.

$A$ análise da temperatura define um clima de altitude com características de subtropical. A distribuição da pluviosidade esboça um ritmo tropical.

Nos altos campos, a distribuição da vegetaçao de campo e mata constitui um mosaico típico, com uma certa organização relacionada às formas de relevo, à rede de drenagem e à formaçð̄es superficiais. Nas bordas e nas áreas muito dissecadas do planalto esse mosaico altera-se.

No topo dos morros e no setor mamelonizado das vertentes, predominam campos de altitude. Matas ocupam o setor inferior das vertentes convexas, as vertentes retilíneas e os anfiteatros de erosão (Fig. 7).

METODOLOGIA E TECNICAS A metodologia adotada apóia-se nos três níveis de abordagem dos fatos geomorfológicos propostos por Ab'Saber (1969): compartimentação topográfica e formas de relevo, estudo da estrutura superficial e da fisiologia da paisagem. A compartimentação efetuada nos altos campos do planalto refere-se ds formas menores do relevo, compreendidas na VI ordem de grandeza da Classificação Taxonômica de Cailleux-Tricart (Tricart, 1965). Nessas unidades, o modelado reflete sobretudo a influência do fator morfodinâmico. Marcados por diferenças nítidas de topografia, hidrologia, formaçðes superficiais e vegetação, os compartimentos reconhecidos nåo correspondem apenas a compartimentos topográficos mas a compartimentos geomorfológicos nos quais se integram os três níveis de abordagem. Em tais unidades, as interações alteração-morfogênese são evidentes.

Consideram-se formaçðes superficiais todos os materiais de cobertura, provenientes da alteração das rochas in situ ou de transporte e deposição, numa conceituação equivalente à de Dewolf (1965).

As técnicas de trabalho de campo e aerofotointerpretação empregadas no reconhecimento e caracterização dos compartimentos geomorfológicos e de suas formaçð̌es superficiais estão parcialmente descritas em trabalho anterior (Modenesi, 1974). $O$ reconhecimento das formaçoes superficiais efetuou-se a partir da compartimentaçåo topomorfológica, com escolha de perfis-tipo 
para a caracterização granulométrica e mineralógica dos materiais de cada situação. Nas planícies fluviais foram consideradas apenas as rampas de colúvio e a rocha alterada sob os depósitos de baixos terraços com cascalho. Os materiais de várzea, sujeitos à hidromorfia, com processos especiais de alteração, não foram estudados.

O estudo do tipo e grau de alteraça (Melfi e Pedro, 1977) das formaçőes superficiais restringiu-se à área de rochas quartzo-feldspáticas da sequência ortossialférrica, procurando eliminar uma das variáveis da alteração, a rocha; entretanto, a diferença entre rochas granitóides e migmatitos estromatíticos nåo permitiu eliminá-la totalmente. Restam a considerar o tempo e a intensidade de lixiviaçåo.

O grau de intemperismo foi definido, principalmente, pela justaposição das seqüências mineralógicas específicas dos feldspatos, micas, quartzo e minerais de neogênese (Wackermann e Modenesi, 1980). Em cada compartimento geomorfologico e/ou setor de compartimento, foi considerada a variação local da intensidade da erosão e seus reflexos na exposição de zonas mais ou menos evoluídas dos perfis. A cronologia relativa de alteração importa caracterizar os materiais mais evoluídos e definir o grau máximo de alteração em cada compartimento.

Conforme as características dos materiais analisados, adotaram-se técnicas petrográficas ou pedologicas. $\mathrm{Na}$ rocha alterada, a amostragem foi sempre feita entre 20 e $50 \mathrm{~cm}$ de profundidade. Nos materiais incoerentes, depósitos e solos, segundo camadas ou horizontes definidos morfologicamente em campo.

A análise granulométrica foi feita por peneiramento a seco para as fraçðes grosseiras e por pipetagem para as finas, segundo técnicas adotadas pelo Laboratório de Geoquímica do Instituto de Geociências, USP, onde foram executadas as análises.

A mineralogia qualitativa forneceu dados sobre a alteração dos minerais primários (feldspatos, quartzo e micas) e permitiu identificar os minerais secundários de alteração (óxidos e hidróxidos de alumínio e ferro, e argilo-minerais). Foram realizadas mais de 220 análises por difração dos raios $\mathrm{X}$ em amostras totais de rocha alterada, solo e crostas reduzidas a pó e nas fraçóes argila, silte e areia dos materiais incoerentes (solo e rocha alterada). $\mathrm{Na}$ fração areia (de 0,5 a $0,125 \mathrm{~mm}$ ), esta análise foi precedida da separação dos minerais sob a lupa binocular.

A determinação dos minerais argilosos a partir da amostra orientada, saturada com cloreto de magnésio, fez-se pela análise in natura e com ensaios de aquecimento $\left(350\right.$ e $550^{\circ} \mathrm{C}$ ) e saturação com etilenoglicol. Materiais pedogenizados foram tratados com água oxigenada para eliminação da matéria orgânica.

Os minerais 2:1 hidroxialuminosos foram identificados por teste de aquecimento progressivo (110-200$350-550^{\circ} \mathrm{C}$ ), em amostra previamente deferrificada e saturada com cloreto de potássio, segundo procedimento descrito por Robert (1975).

Microscopia sob luz polarizada, aplicada em 72 lâminas delgadas de rocha alterada e crostas, permitiu definir a filiação dos minerais secundários de alteração e a importância das remobilizaçð̋es ao nível da microestrutura.
A mineralogia quantitativa teve por fim caracterizar o grau de intemperismo dos materiais de cobertura. Análises termoponderais, efetuadas na Escola Senai Armando de Arruda Pereira e executadas apenas num perfil em cada compartimento, forneceram as porcentagens de caulinita e gibbsita das amostras totais de rocha alterada e do horizonte superficial dos solos.

\section{COMPARTIMENTAÇ̃̃O GEOMORFOLOGICA E CARACTERISTICAS MORFOLOGICAS DAS FOR- MAÇÖES SUPERFICIAIS O planalto de Campos} do Jordão possui uma individualidade própria em termos de rede de vales, formas de dissecaçå lateral relacionada aos afluentes do Capivari e tipologia das vertentes regionais.

Ao nivel das formas menores do relevo, uma nítida compartimentação caracteriza os altos campos do planalto (Fig. 7). Âs diferenças topomor fológicas correspondem variaçōes da hidrologia das vertentes, dos materiais de cobertura e da vegetação.

Formaçôes superficiais diferenciadas ocorrem em topo de interflúvio, vertentes convexas, vertentes retilíneas, anfiteatros de erosão e planícies fluviais. Há mamelonização do topo dos morros e do setor superior das encostas, e o setor inferior é geralmente retilíneo. Acima dos $1.900 \mathrm{~m}$, nas áreas mais preservadas das açð̃es erosivas, a mamelonização atinge também o setor inferior.

TOPO DOS INTERFLÚVIOS No trecho do planalto drenado pelos afluentes da margem direita do alto Sapucaí-Guaçu, os interflúvios têm seus topos nivelados a altitudes decrescentes, do divisor da Mantiqueira (Fazenda da Lavrinha-São José dos Alpes, $2.007 \mathrm{~m}$, morro de Itapeva $1.950 \mathrm{~m}$ ) ao vale do Sapucaí (Vila Capivari, $1.573 \mathrm{~m}$ ). Níveis topográficos embutidos na porção mais elevada do planalto $(1.900-2.007 \mathrm{~m})$ sucedem-se a altitudes de $1.800-1.820 \mathrm{~m}, 1.710-1.740 \mathrm{~m}$ e 1.640 $1.660 \mathrm{~m}$ (Fig. 6). Nos dois níveis mais baixos predominam migmatitos; acima, rochas granitóides.

SOLO As formaçōes superficiais do topo dos morros são caracterizadas por solo pouco espesso sobre linha de seixos e rocha alterada. Localmente, as linhas de seixos podem aflorar por ação do escoamento superficial.

No recobrimento raso, com espessura de 10 a $30 \mathrm{~cm}$ e; excepcionalmente, $50 \mathrm{~cm}$, desenvolve-se um horizonte A friável de cor preta ou bruno-escura. Gråos de areia clara, lavada, destacam-se com nitidez nos solos mais escuros, comuns principalmente acima dos $1.800 \mathrm{~m}$. Crostas ferruginosas podem marcar a base do horizonte A em contato a linha de seixos ou com a rocha alterada. Acima dos $1.800 \mathrm{~m}$ predominam matizes 10 YR e, nos morros mais baixos, 7,5 YR. Esses solos correspondem aos descritos por Oliveira et alii (1975) como litossolos ou solos com B incipiente pouco espesso (inferior a $20 \mathrm{~cm}$ ).

Os perfis desenvolvidos sobre granito apresentam cascalho de quartzo e maior porcentagem de areia grossa. Com a diminuição da altitude observa-se um aumento do teor médio de argila (de $23 \%$ a $53 \%$ ) e uma diminuiç̃o das frações areia (de $60 \%$ a $37 \%$ ) e silte (de $18 \%$ a $10 \%$ ). A textura predominante passa de limo-areno-bar- 
renta acima dos $1.900 \mathrm{~m}$ a barrenta e argilosa nos morros nivelados a $1.800-1.820 \mathrm{~m}$ e a argilosa abaixo dos $1.740 \mathrm{~m}$.

No horizonte $\mathrm{A}$ os valores de $\mathrm{pH}$ em água variam de 4,7 a 5,2 .

O contato do material de recobrimento com a rocha subjacente é quase sempre marcado por linha de seixos de quartzito e da rocha local. Acima dos $1.800 \mathrm{~m}$ podem ocorrer, principalmente na borda dos morros, blocos de lateritas aluminosas de até $40 \mathrm{~cm}$ de eixo maior. Nessas altitudes, são mais freqüentes nódulos (concentraçðes de estrutura indiferenciada) e seixos lamelares brancos inferiores a $2 \mathrm{~cm}$. Nos morros de 1.710$1.740 \mathrm{~m}$ são comuns nódulos tubuliformes ou radiciformes com diâmetro médio de $1 \mathrm{~cm}$ e comprimento de até $5 \mathrm{~cm}$.

ROCHA ALTERADA A rocha subjacente apresenta variaçð̃es sensiveis de coesão e cor. Tons avermelhados são mais comuns. Tons claros ocorrem geralmente acima dos $1.800 \mathrm{~m} \mathrm{e}$, abaixo deste nivel, apenas quando relacionados a fenômenos de hidromorfia. Na maioria das vezes, conserva ainda a sua estrutura outras, geralmente em bolsð̃es descontínuos, e comporta-se como um horizonte $\mathrm{C}$ de solo. A falta de boas exposiçóes impediu a observação da profundidade da alteração. A rocha fresca nunca foi atingida.

Nas áreas mais elevadas do planalto, sob o horizonte $A$ escuro a a linha de seixos, a superficie da rocha pode estar revestida por fina crosta ferruginosa. Crostas milimétricas de gibbsita foram observadas em altitudes proximas a $1.800 \mathrm{~m}$. Nos morros mais baixos, a alteração dos estromatitos homogêneos de caráter oftalmítico exibe estrutura alveolar típica.

Entre o morro de Itapeva e o Hotel Vila Inglesa, em altitudes de 1.930 a $1.800 \mathrm{~m}$, na borda do topo dos morros (Fig. 6), afloram restos de antigas lateritas (rocha muito alterada, endurecida, rica em hidróxidos de alumínio e ferro) ou apenas blocos em linhas de seixos. Acima dos $1.900 \mathrm{~m}$ são pouco densas, rugosas, escoriáceas e ferruginizadas em superfície. Podem apresentar pequenos alvéolos algumas vezes revestidos por crostas brancas de gibbsita. Em migmatitos, as estruturas estão nitidamente preservadas com aparecimento de bandas brancas endurecidas, ricas em gibbsita e bandas róseas ou avermelhadas mais friáveis, com grãos de quartzo. Em rocha granitóide observam-se manchas claras mais endurecidas e manchas avermelhadas mais friáveis com grãos de quartzo dispersos na massa. Vestígios da estrutura original permanecem apenas ao nivel da microestrutura.

As lateritas dos morros de $1.800 \mathrm{~m}$, apesar de mais densas, apresentam o mesmo aspecto escoriáceo das anteriores. Seus alvéolos são freqtentemente preenchidos por argila vermelha. A estrutura está sempre preservada, seja nas rochas orientadas, seja nas granitóides.

VERTENTES Vertentes convexas desenvolvem-se principalmente sobre rochas granitódes e migmatitos estromatíticos. Na maior parte dos altos campos, o setor inferior é retilíneo e nas áreas mais elevadas da borda do planalto a convexidade atinge a base das vertentes. Em presença de rampas de colúvio (Bigarella e Mousi- nho, 1965), ocorrem setores côncavos no contato com a planície aluvial.

O setor mamelonado das vertentes é recoberto por vegetação de campo. As vertentes incisas (vertentes retilíneas, setor retilíneo de vertente convexa e anfiteatros de erosão) são áreas de mata (Fig. 7).

Vertentes retilíneas são comuns sobre quartzitos. Ocorrem ainda sobre outras rochas, em áreas de maior amplitude e dissecação do relevo, freqüentemente relacionadas a alinhamentos estruturais.

Nas vertentes convexas é generalizada a ocorrência de anfiteatros de erosão, reentrâncias provocadas por importantes e profundos movimentos de massa. Os depósitos correlativos destas formas acham-se preservados no fundo dos anfiteatros na sua parte basal e no topo. Constituem depósitos conglomeráticos, produto de remanejamentos do regolito ou do regolito e de materiais anteriormente pedogenizados.

SOLO As características morfológicas dos materiais de vertente variam muito. No setor mamelonado, o recobrimento é pouco espesso e os solos são equivalentes aos do topo dos morros. Nos patamares, nas vertentes de todos os tipos, podem ocorrer materiais mais espes. sos, com 2 ou até $3 \mathrm{~m}$, nos quais se desenvolvem perfis semelhantes aos dos solos de Campos do Jordåo (Comissão de Solos, 1960), ou cambissolos de Oliveira et alii (1975), e aos solos com B textural ou B latossólico, descritos pelos mesmos autores para o Parque Estadual de Campos do Jordão.

São freqüentes perfís complexos com horizontes $\mathbf{A}$ enterrados, principalmente nos anfiteatros. Na Serra do Baú, no morro da Pedra de Fogo e no Imbiri, em vertentes ou ombreiras a altitudes de $1.700-1.780 \mathrm{~m}$ (Fig. 6), ocorrem com frequiência materiais vermelhos, com características morfológicas de horizontes B latossóli$\cos$, sob outros mais amarelados, com horizontes $\mathbf{A}$ brunos ou negros. Os materiais vermelhos apresentam, quase sempre, indícios de remanejamento: linhas de seixos basais ou inclusão de grânulos, seixos e blocos de rocha pouco alterada.

No horizonte superficial dos solos de vertente há uma tendência ao aumento do teor médio de argila com a diminuição da altitude (de $23,5 \%$ a $46 \%$ ). Os teores de silte såo muito variados (de $5 \%$ a $33 \%$ ) e freqüentemente superiores aos dos materiais de topo. Nas vertentes mamelonadas, o horizonte $\mathrm{A}$ é geralmente menos argiloso que nos solos do topo dos morros.

Os valores de ph em água do horizonte superficial estão entre 4,3 e 5,4 . Sob mata, situam-se entre 4,7 e 5,2 .

Nos perfis rasos, as linhas de seixos estão no contato do material de recobrimento com a rocha alterada. Nos perfis mais espessos podem ocorrer na base do horizonte $\mathbf{A}$ ou no contato com a rocha e, algumas vezes, nas duas posiçóes: Os clásticos são de composição litológica semelhante a das linhas de seixos do topo dos interflúvios. Nåo ocorrem nódulos de argila e os de gibbsita são mais raros.

ROCHA ALTERADA A rocha aflora apenas em alguns setores mais íngremes das vertentes e no fundo dos anfiteatros. Na maioria das vezes, apesar de altera- 


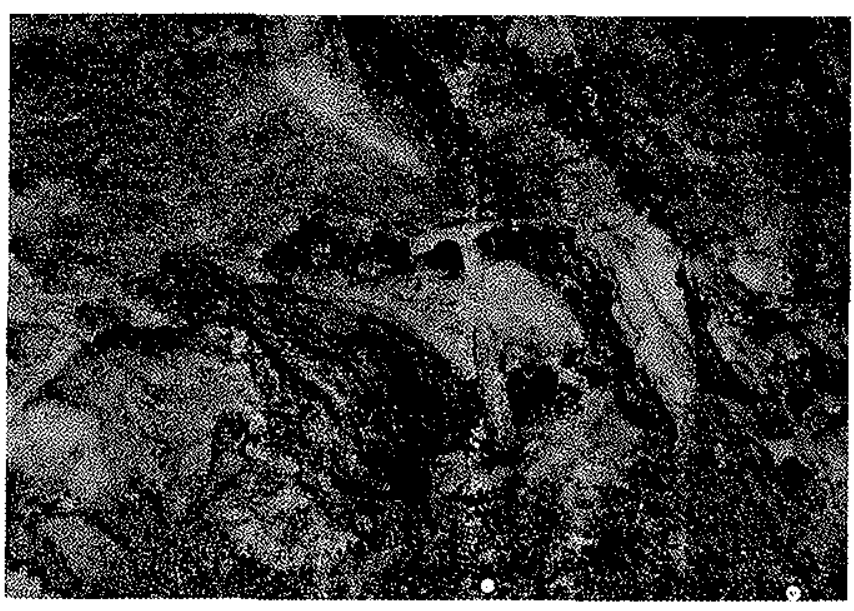

Figura 2 - Bauxitização em rocha granitóide pouco alterada, com individualização de zonas ferruginosas e gibbsíticas, sem destruição da estrutura da rocha-matriz

da, conserva ainda sua estrutura. Como nos interflúvios, tons acinzentados podem ocorrer acima dos $1.800 \mathrm{~m}$, nunca abaixo. Em vertentes mamelonadas, na área mais elevada do planalto (Fig. 6), processos de alteraçåo com individualização do ferro e alumínio (Fig. 2) caracterizam a bauxitização de rochas ácidas.

Nas vertentes de todos os tipos, em perfis desenvolvidos sobre colúvios e/ou material alterado in situ, é comum a superposição de materiais vermelhos por outros amarelados. A diferença de cores não reflete maior ou menor riqueza dos materiais originais em minerais ferromagnesianos. Tons amarelados ocorrem indiferentemente sobre materiais ricos em biotita ou em muscovita. Em certos depósitos, o abrupto contraste de cor resulta da superposição de camadas diferentes, separadas, algumas vezes, por tênues linhas de seixos. Mas, em grande número de perfis de solo, a passagem é gradual, corresponde a uma substituição gradativa da cor vermelha por cores bruno-amareladas, sem descontinuidades de qualquer tipo.

\section{PLANícIES FLUVIAIS Ao longo do Sapucaí-} Guaçu e de seus afluentes principais, desenvolvem-se pequenas planícies fluviais separadas por segmentos de rio encaixados. Nessas planícies alveolares ocorrem, acima da várzea atual, restos de baixos terraços com cascalho recobertos por materiais de vertente. Os coluvionamentos penetram algumas vezes até a várzea formando rampas de colúvio.

As cascalheiras, com espessura de 40 a $50 \mathrm{~cm}$, provavelmente reduzida pela açao de coluvionamentos posteriores, são constituídas por seixos de quartzo, principalmente subarredondados, com eixo maior de 4 a 20 $\mathrm{cm}$. Repousam sobre a rocha alterada in situ com tons claros, estrutura conservada e sinais mais ou menos evidentes de hidromorfia. Sobre os depósitos de cascalho podem ocorrer materiais escuros, de textura fina, provavelmente relacionados a níveis de várzea suspensos.

As rampas de colúvio têm espessura, composição e granulometria variadas. Apresentam com frequência camadas conglomeráticas e/ou estratos enriquecidos em matéria orgânica.
$\mathrm{Na}$ planície de inundaçăo, dificuldades de escoamento definem setores de várzea turfosa.

CARACTERÍSTICAS MINERALÓGICAS DAS FORMAÇŌES SUPERFICIAIS A seguir será descrita a mineralogia das formaçðes superficiais, solos e rocha alterada em cada compartimento geomorfologico.

TOPO DOS INTERFLUVIOS SOLOS Os solos do topo dos morros apresentam, de modo geral, uma mineralogia semelhante, entretanto algumas características parecem diferenciar materiais situados acima e abaixo dos $1.800 \mathrm{~m}$. Acima dos $1.800 \mathrm{~m}$, a fração areia grossa $(0,5-1 \mathrm{~mm})$ é constituída por restos de rocha (de $19 \%$ a $69 \%$ ), quartzo (de $29 \%$ a $53 \%$, e mais frequientemente $50 \%$ ), feldspatos alterados (até $25 \%$ ), opacos alterados (até 9\%) e traços de micas. Abaixo dos $1.800 \mathrm{~m}$, o quartzo é o mineral predominante (de $78 \%$ a $92 \%$ ), ocorrendo ainda feldspatos alterados e restos de rocha em menor proporção (até $5 \%$ ), opacos alterados ( $1 \%$ ou traços) e micas (traços).

O quartzo representa mais de $95 \%$ dos grãos da fração areia média (de 0,5 a $0,25 \mathrm{~mm}$ ). Restos de rocha podem constituir até $4 \%$, feldspatos e opacos alterados, $2 \%$ e micas, $1 \%$. Materiais com até $54 \%$ de agregados de argila vermelha e quartzo, pseudo-areias, ocorrem excepcionalmente a 1.920 e $1.740 \mathrm{~m}$ de altitude.

$\mathrm{Na}$ fraçào areia fina $(0,25-0,53 \mathrm{~mm})$, a quantidade de micas pode aumentar dependendo da riqueza da rocha subjacente neste mineral.

Os difratogramas de raios $\mathbf{X}$ da fração areia mostram, além do quartzo, picos importantes de gibbsita e traços de caulinita correspondentes à alteraçåo de feldspatos isolados e restos de rocha.

Os minerais mais importantes na fração silte são a gibbsita e o quartzo. Traços de micas e microclínio ocorrem em alguns solos menos evoluídos.

$\mathrm{Na}$ fração argila, a caulinita destaca-se, ao lado da gibbsita, como o principal mineral secundário de alteração. Acima dos $1.900 \mathrm{~m}$, a gibbsita é mais importante. Minerais interestratificados e traços de micas são freqüentes nos dois niveis topográficos inferiores.

Caulinita e gibbsita constituem de $37 \%$ a $76 \%$ da fração mineral dos solos do topo dos morros. Os teores de caulinita variam de $18 \%$ a $57 \%$ e os de gibbsita, de $12 \%$ a $21 \%$. A soma caulinita-gibbsita tende a aumentar com a diminuiçåo da altitude, paralelamente ao aumento de importância das fraçðes argila e silte.

Os nódulos e pequenos seixos lamelares brancos das linhas de seixos dos morros mais elevados såo constituídos quase exclusivamente por gibbsita. Nódulos tubuliformrs ou radiciformes e seus fragmentos, comuns em altitudes de $1.710-1.740 \mathrm{~m}$, apresentam, além de gibbsita, caulinita, quartzo e traços de micas, goethita e hematita.

ROCHA ALTERADA No regolito, em altitudes superiores a $1.900 \mathrm{~m}$, os feldspatos estão alterados em gibbsita com formação de matriz micro ou macrocristalina (Figs. 3 e 5). Em rocha menos alterada, ocorre caulinita criptocristalina pseudomórfica sobre feldspato ou há substituição por gibbsita microcristalina. Foram observados sinais de dissolução total em feldspatos e no fundo gibbsítico deles proveniente. 


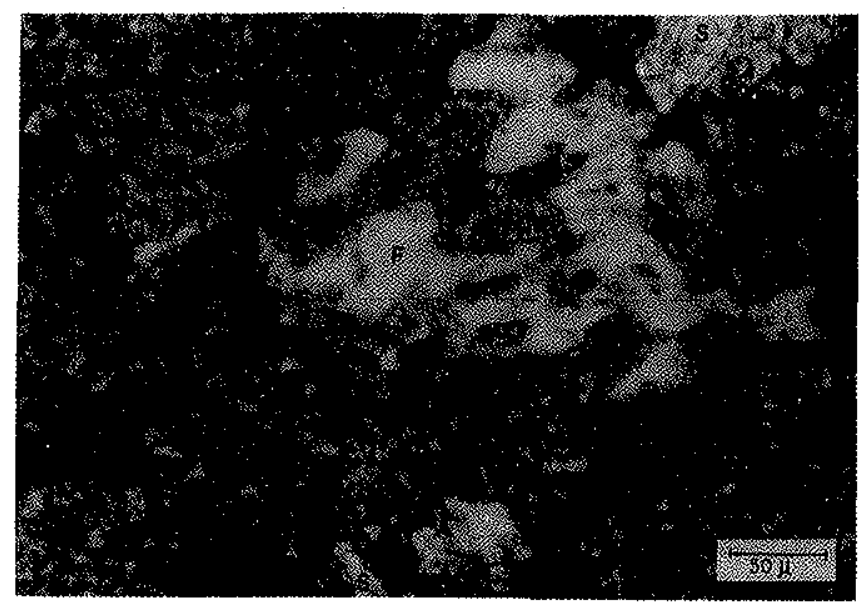

Figura 3 - Residuos de feldspato (F) corroído e poroso envolvidos por gibbsita macrocristalina $(\mathrm{Gm})$; notar a passagem abrupta, sem fase intermediária. Sericitas (S) residuais

O quartzo ocorre relativamente bem conservado, mesmo em presença de gibbisitização acentuada. Veios quartzofeldspáticos, isolados em granito, alteram-se exclusivamente em gibbsita, algumas vezes com pulverização dos quartzos.

A muscovita ocorre sã ou com alteração incipiente. Biotitas alteram-se em gibbsita e, nos materiais menos evoluidos, em caulinita. Argilo-minerais 2:1 da provável transformaçăo das cloritas apresentam picos entre 11,04 e 14,77 $\AA$. Submetidos a glicolagem e aquecimento a $550^{\circ} \mathrm{C}$, comportaram-se como vermiculitas; teste suplementar de aquecimento mostrou uma valiação progressiva da distância da primeira reflexão basal até $10,27 \AA$, caracterizando o comportamento dos minerais hidroxialuminosos (Robert, 1975).

Os principais minerais residuais são quartzo e muscovita. Hidróxidos de ferro ocorrem como impregnações periféricas em muscovitas e resíduos de remobilização interlamelar em biotitas. Grânulos de hematita são comuns dispersos na matriz gibbsítica, principalmente nas zonas bem cristalizadas.

O total de caulinita e gibbsita obtido numa amostra de rocha, ainda com feldspatos residuais, foi de $63 \%$, com quantidades equivalentes dos dois minerais (32\% e $31 \%$ ).

Em altitudes de $1.800-1.820 \mathrm{~m}$, a alteraçåo dos feldspatos e da muscovita é equivalente à observada no topo dos morros mais elevados. $O$ quartzo apresenta-se fraturado e corroido com preenchimento dos vazios por gibbsita.

Biotitas alteram-se em caulinita pseudomorfa, algumas vezes com inclusōes de gibbsita (Fig. 4). Em materiais pouco evoluidos ocorrem argilo-minerais $2: 1$ hidroxialuminosos. Parece esboçar-se uma dicotomia de alteração, com caulinização das micas e gibbsitização dos feldspatos (Fig. 4).

Os principais minerais residuais săo o quartzo e a muscovita mas, com maior freqüência que nos morros mais elevados, permanecem ainda anfibólios, albita e opacos (ilmenita, magnetita).

Goethita pseudomórfica ocorre em micas. Impregnaçóes dispersas de goethita e hematita são comuns no

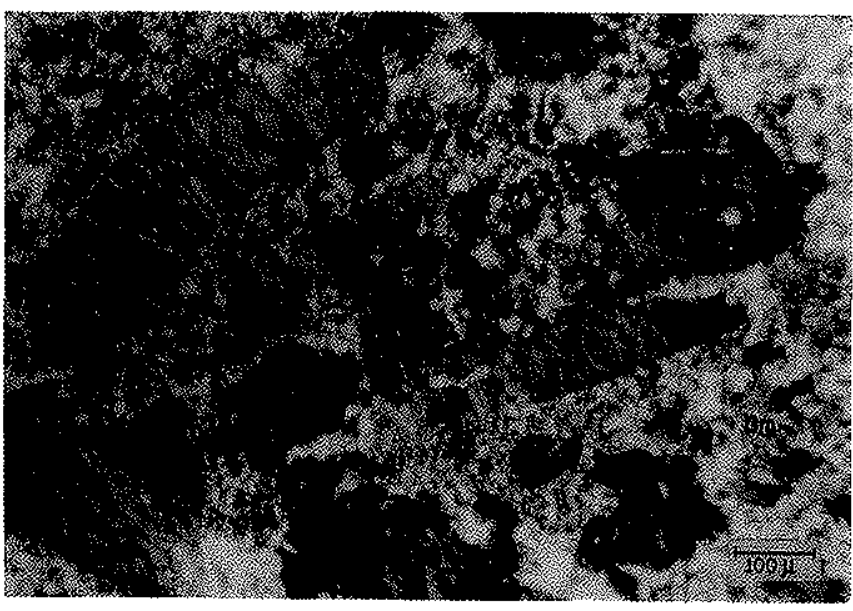

Figura 4 - Gibbsita macrocristalina (Gm) caótica proveniente da alteraçăo dos feldspatos. Caulinita criptocristalina (C) substituindo muscovita com conservação da forma e das orientaçðes mineralógicas. Pequenas inclusões de gibbsita paralelas às antigas lamelas

fundo de caulinita criptocristalina e grânulos de hematita no fundo gibbsítico.

Nos materiais mais evoluídos, caulinita e gibbsita constituem $68 \%$ da amostra total com teores de $13 \%$ e $55 \%$, respectivamente.

Nos morros de 1.710-1.740 m, feldspatos alteramse de preferência em gibbsita mas também em caulinita. Em veios quartzofeldspáticos, isolados em migmatitos, pode predominar a caulinita. O quartzo, na maioria das vezes bem conservado, pode ter fissuras e vazios preenchidos por gibbsita ou gibbsita e ferro.

A alteração das muscovitas é caracterizada por caulinização parcial. Biotitas alteram-se em gibbsita ou, com maior frequência em caulinita, algumas vezes com inclusðes de gibbsita. Sericitas apresentam-se frescas ou parcialmente alteradas.

Os principais minerais residuais são quartzo e muscovita, e, mais raramente, albita. Em rochas sericitizadas e saussuritizadas, sericitas e epídotos.

Hematita e goethita ocorrem em micas e anfibblios, hematita em grânulos dispersos no fundo gibbsítico e goethita impregnado caulinita criptocristalina. A ferruginização dos quartzos é rara.

O total de caulinita e gibbsita é de $50 \%$, o menor encontrado em posição de topo, com apenas $9 \%$ de gibbsita.

A estrutura alveolar, característica da alteraçåo dos migmatitos estromatíticos nesta altitude, resulta da alteração total dos porfiroblastos de feldspato e, algumas vezes, de outros minerais, até mesmo do quartzo.

Nas colinas niveladas a 1.640-1.660 $\mathrm{m}$, há gibbsitizaçâo dos feldspatos; a caulinita caracteriza apenas estágios iniciais de evoluçåo. Foram observados sinais de dissolução em feldspatos residuais e no fundo gibbsítico. O quartzo, intato ou fraturado, pode ter os espaços entre os cristais e as fissuras preenchidos por gibbsita.

Caulinita pseudomórfica, com eventuais intercalaçōes ou inclusðes de gibbsita, caracteriza a alteração das muscovitas; biotitas alteram-se como no nível anterior. Algumas sericitas estão caulinizadas. 
Os minerais residuais são os mesmos encontrados nos morros de $1.710-1.740 \mathrm{~m}$. Óxidos e hidróxidos de ferro aparecem dispersos em zonas gibbsíticas ou como resíduos interlamelares em biotitas. Não há reorganizaçăo ao nivel da microestrutura.

Caulinita e gibbsita correspondem a $68 \%$ do total da rocha alterada, com nítida predominância de gibbsita $(53 \%)$.

Os afloramentos da borda do topo dos morros mais elevados, produto residual do intemperismo de rochas granitóides e migmatitos, representam o grau máximo de evolução observado na área (Fig. 5).

Gibbsita ocorre em feldspatos e micas ou em matriz de granulação variada, com eventuais concentraçðes esparsas (nódulos, filððes e geodos). Em biotitas há substituição das antigas lamelas, com deslocamento periférico dos óxidos de ferro e neogênese de gibbsita. Observa-se uma tendência à destruição da forma das micas. $O$ quartzo conservado ou fraturado, com preenchimento de gibbsita e/ou ferro, é o único mineral residual. Há reorganização do ferro ao nivel da microestrutura, com preenchimento de fissuras, revestimento da parede dos vazios e formação de massas de ferro argilosas zonadas (papules).

Esses materiais constituem lateritas primárias (Harrison, 1933; Erhart, 1973) definidas pela preservação das estruturas da rocha-matriz e por processos de acumulação relativa. Caracterizadas por gibbsitização geral, são bauxitas de cobertura laterítica (Lelong et alii, 1976), produtos residuais aluminosos ou aluminoferruginosos resultantes de intemperismo intenso.

Nas duas dosagens efetuadas, caulinita e gibbsita representam, respectivamente, $57 \%$ e $72 \%$ do total da rocha, com nítida predominância de gibbsita $(43 \% \mathrm{e}$ $52 \%$ ). Esses dados correspondem a teores de alumina de $33 \%$ e $\mathbf{4 2 \%}$ (calculados a partir das fórmulas da caulinita e gibbsita, e das respectivas análises termoponderais); um pouco inferiores aos teores citados por vários auto-

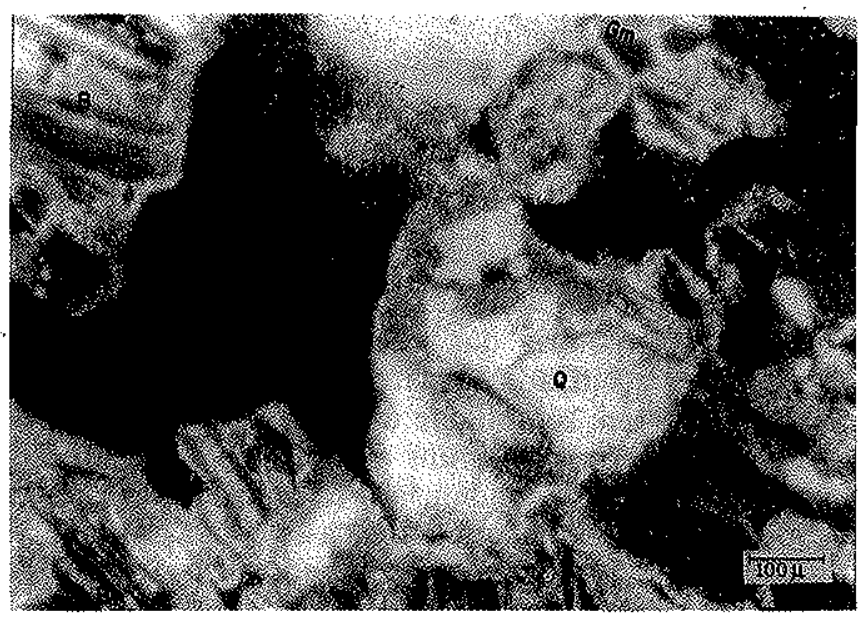

Figura 5 - Lâmina petrográfica de laterita aluminoferruginosa. Forte porosidade com conservação da estrutura. Resíduos de antigos quartzos (Q) fragmentados, corroídos, envolvidos e invadidos por gibbsita de granulação média. Antigas biotitas (B) substituídas por gibbsita e lamelas de hematita (H) paralelas às lamelas iniciais. Oxidos de ferro (Fe) na periferia dos poros e em massas zonadas no interior dos mesmos. Concentraçôs de gibbsita macrocristalina (Gm) na borda dos poros res (Lelong et alii, 1976) para as lateritas aluminoferruginosas ou bauxitas impuras (de $44,3 \%$ a $46,8 \%$ ), refletem provavelmente a importância do quartzo como mineral residual.

VERTENTES SOLOS Morfológica e mineralogicamente semelhantes aos materiais de topo, os solos rasos das vertentes mamelonadas exibem um grau de alteração um pouco menor.

$\mathrm{Na}$ fração areia grossa predominam grãos de quartzo com porcentagens de até $70 \%$. Ocorrem ainda restos de rocha (de $10 \%$ a 57\%), feldspatos alterados (até $33 \%$ ) e, com menor importância (inferior a 6\%), minerais opacos alterados, micas e agregados de argila ferruginizada e grãos de quartzo. A areia média é constituída quase exclusivamente (de $91 \%$ a $96 \%$ ) por grãos de quartzo e, em menor proporção, por restos de rocha (até 6\%), feldspato (de $1 \%$ a $8 \%$ ), opacos alterados $(8 \%)$ e agregados de argila $(1 \%)$.

Como nos solos dos topos, há gibbsita na fração areia. $\mathrm{Na}$ fração silte ocorrem com importância quartzo e gibbsita, e, secundariamente, micas, microclínio e minerais interestratificados. $\mathrm{Na}$ fração argila predomina ora gibbsita ora caulinita, ocorrendo ainda, com frequêencia, vermiculita aluminosa.

Gibbsita e caulinita representam de $32 \%$ a $43 \%$ da fraçăo mineral desses solos. Os teores de caulinita oscilam entre $14 \%$ e $24 \%$ e os de gibbsita, entre $12 \%$ e $26 \%$.

Nas vertentes incisas, perfis mais espessos podem apresentar uma modificação das características mineralógicas em profundidade nos horizontes B ou B/C. Nas fraçðes argila e silte, há um aumento de importância da caulinita em relação à gibbsita. As micas ocorrem menos alteradas e os minerais interestratificados são raros. $\mathrm{Na}$ fraçăo silte, diminui a importância do quartzo. As areias apresentam uma maior quantidade de minerais residuais (micas, feldspatos, opacos). Esta observação é confirmada pela referência de Oliveira et alii (1975) a porcentagens relativamente elevadas de feldspatos (de $5 \%$ a $42 \%$ ) na fração grosseira dos cambissolos e podzólicos vermelho-amarelos do Parque Estadual de Campos do Jordão.

No horizonte A de um solo em setor inciso de vertente, a soma caulinita-gibbsita representa apenas $13 \%$ do total, com $8 \%$ de gibbsita.

ROCHA ALTERADA Nos diferentes setores das encostas, as características da rocha alterada dependem, em grande parte, da variaçăo de intensidade dos fenômenos erosivos e do recente entalhe fluvial, responsáveis pela maior ou menor permanência dos materiais.

No setor mamelonado, a alteração dos minerais primários é semelhante à observada nas respectivas posiçðes de topo. Ao nível da microestrutura, a remobilização e reorganização da gibbsita é comum e a dos óxidos e hidróxidos de ferro ocorre apenas na transição para o horizonte $\mathrm{C}$. Os totais de caulinita e gibbsita (de $52 \%$ a $65 \%$ ) situam-se dentro daqueles valores obtidos no topo dos interflúvios (Fig. 7), geralmente com predominância de caulinita (de $25 \%$ a $41 \%$ ).

Nas vertentes convexas da borda do planalto, especialmente acima dos $1.900 \mathrm{~m}$, são observados fenômenos de bauxitização em processo sobre rochas granitói- 
des. A individualização do ferro e alumínio se faz sem perda da estrutura da rocha-matriz (Fig. 2). A gibbsita é o mineral secundário mais importante, ocorre em feldspatos e micas, e mais raramente sob a forma de geodos e filoes. Permanecem quartzo e muscovita intatos, microclínios porosos e biotita pouco alterada.

Uma lixiviação intensa seria responsável pela transformação direta dos minerais silicatados em gibbsita (Fig. 3), definindo bauxitas primárias em rochas quartzofeldspáticas. Como observaram Lelong et alii (1976), sob condiçðes intensas de lixiviaçăo, os limites de solubilidade dos minerais silicatados não são necessariamente atingidos e a evolução pode levar diretamente ao estádio bauxítico antes da destruição total dos feldspatos e do quartzo.

Nas vertentes retilíneas e no setor retilíneo das vertentes convexas, são frequientes afloramentos de rocha sa ou pouco alterada. Nos materiais mais evoluidos, os feldspatos eståo alterados em gibbsita ou caulinita. $O$ quartzo, geralmente conservado, pode estar fissurado ou corroído, algumas vezes com preenchimento de gibbsita. Muscovitas e sericitas, sãs ou parcialmente caulinizadas. Biotitas alteram-se em caulinita ou gibbsita sempre com ferruginização. Os minerais residuais são quartzo, muscovita, sericita, epídoto e, nos materiais menos intemperizados das vertentes incisas, microclínio, albita e biotita. Não há remobilizaçăo do ferro e apenas sinais incipientes de reorganizaça da gibbsita. Caulinita e gibbsita representam $37 \%$ do total da rocha com predominância de caulinita $(28 \%)$.

Nos anfiteatros de erosão relacionados aos dois níveis topográficos mais baixos, a caulinita é o principal mineral secundário. Interestratificados ocorrem em biotitas. Não se observa remobilização de gibbsita ou ferro. Resíduos de minerais primários pouco resistentes e maior frequência de micas ou interestratificados definem uma alteraçå incompleta das rochas.

Acima dos $1.800 \mathrm{~m}$, a gibbsita é mais importante. Gibbsitização total dos feldspatos, corrosão dos quartzos, remobilização e reorganizaçăo da gibbsita e ferro foram observadas ao lado de biotitas pouco alteradas. Micas e, mais raramente, microclínio e albita podem ocorrer como residuais.

Nos depósitos do interior dos anfiteatros, caulinita e micas são, além do quartzo, os minerais predominantes. A gibbsita pode ser importante apenas acima dos $1.900 \mathrm{~m}$. Traços de minerais instáveis são raros. As sequuências de alteração observadas nesses depósitos são normais, com materiais mais intemperizados recobrindo outros menos alterados, como num perfil de solo.

PLANICIES FLUVIAIS Nas planícies alveolares, sob os depósitos de cascalho dos baixos terraços, a alteraçđo da rocha é caracterizada por caulinizaçåo ou dissoluçåo parcial dos feldspatos. Micas alteram-se em caulinita e em argilo-minerais equivalentes às vermiculitas, provavelmente aluminosas; biotitas estão impregnadas por oxidos de ferro. O quartzo ocorre sempre bem conservado. São freqüentes resíduos de minerais primários. Não há evidências de remobilização de ferro e gibbsita. A soma de caulinita-gibbsita, obtida numa amostra de rocha granitóide, é de $43 \%$ com $34 \%$ de caulinita.
Nas rampas de colúvio relacionadas aos morros mais elevados, a gibbsita é o mineral mais importante e, abaixo dos $1.800 \mathrm{~m}$ pode predominar a caulinita. E característica a ocorrência de micas. Em algumas camadas ocorrem ainda traços de microclínio e, mais raramente, de plagioclásio e anfibólio. Nesses depósitos ocorrem sequêencias de alteraçăo inversas ou desordenadas.

\section{O GRAU DE INTEMPERISMO DAS FORMAÇÕES} SUPERFICIAIS E A COMPARTIMENTAÇÃO GEOMORFOLÓGICA No topo dos interflúvios, os solos são rasos, com linha de seixos basal; sua fração mineral, muito evoluida, é constituída quase exclusivamente por quartzo, caulinita e gibbsita. Há um aumento do teor de argila com a diminuiçåo da altitude relacionado, provavelmente, ao substrato migmatito estromatítico, mais pobre em quartzo e rico em micas que os granitos das áreas mais elevadas.

Em altitudes superiores a $1.800 \mathrm{~m}$, a fraçåo areia grossa é mais rica em minerais residuais, em grande parte, já alterados. Na fração argila, caulinita e gibbsita podem predominar independente da altitude dos topos, mas caulinita e minerais interestratificados parecem mais freqüentes abaixo dos $1.800 \mathrm{~m}$. Quartzo e gibbsita são os principais minerais da fração silte.

A correlaçåo das dosagens de caulinita e gibbsita com a posiçăo topográfica dos solos mostra um aumento significativo do teor de caulinita e da soma caulinitagibbsita apenas nas colinas de $1.640-1.660 \mathrm{~m}$. O número reduzido de análises quantitativas não permitiu estabelecer outras relaçðes.

Sob a linha de seixos, a rocha tem sua estrutura geralmente preservada. Constitui material muito intemperizado, com soma caulinita-gibbsita sempre superior a $50 \%$ e predominância de gibbsita (Figs. 6 e 7). Exceçôes, com maior importância de caulinita, ocorrem apenas em alteração incipiente e nos migmatitos estromatíticos com estrutura alveolar, em que os alvéolos correspondem a vazios deixados pela destruição total dos porfiroblastos de feldspato.

A alteração dos feldspatos é caracterizada por gibbsitização. Caulinização ocorre apenas em alteração incipiente ou, algumas vezes, em altitudes de 1.710. $1.740 \mathrm{~m}$. Sinais de dissoluçâo total dos feldspatos foram observados acima dos $1.900 \mathrm{~m}$ e nas colinas de 1.640 $1.660 \mathrm{~m}$.

A muscovita é, com o quartzo, o principal mineral residual. Na maioria das vezes parcialmente alterada pode estar gibbsitizada nas lateritas da borda dos tppos. Biotitas ocorrem totalmente alteradas. Nos estádios de menor evolução são comuns argilo-minerais 2:1 hidroxialuminosos. Uma tendência à caulinização das micas esboça-se aos $1.800 \mathrm{~m}$ e intensifica-se com a diminuição da altitude (Fig. 6).

$O$ quartzo parece mais bem conservado acima dos $1.900 \mathrm{~m}$ e nas colinas mais baixas; nas lateritas e na rocha alterada dos morros de 1.710-1.740 m, está freqüentemente fraturado.

Fenômenos de remobilizaçăo e reorganização da gibbsita são gerais. A reorganização do ferro, com preenchimento de fissuras, revestimento de vazios e formação de massas ferroargilosas zonadas, é típica das lateritas (Fig. 5). Essa reorganizaçăo implica maior poro- 


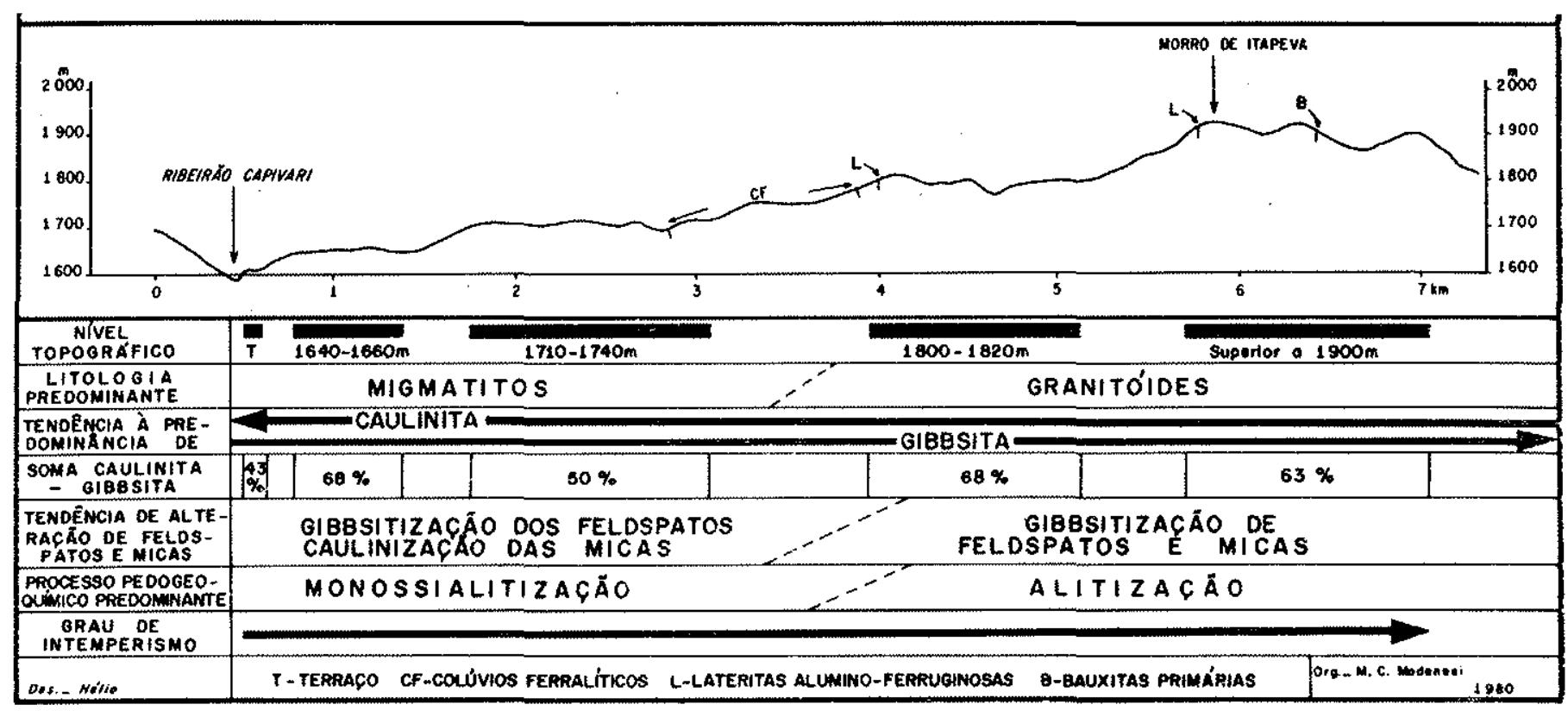

Figura 6 - Perfil transversal do planalto de Campos do Jordão e suas relaçðes com os fenômenos de alteração

sidade e alteraçåo da rocha. Nos topos acima de $1.700 \mathrm{~m}$, podem ocorrer pequenos grânulos de hematita dispersos em matriz gibbsítica.

Nas vertentes, áreas essencialmente dinâmicas da paisagem, erosåo e deposiçăo modificam sensivelmente a distribuição dos materiais de recobrimento. Há maior variaçăo das características morfológicas dos solos, aumento de espessura e um relativo enriquecimento da fraçăo areia. A superposiçăo de solos é freqüente.

No setor mamelonado, relativamente estável, as características morfológicas e mineralógicas dos solos e da rocha alterada são semelhantes ds observadas no topo dos morros mas o grau de intemperismo é um pouco inferior. Na rocha alterada, a importância relativa da gibbsita diminui, com provável exceção nas vertentes mamelonadas acima dos $1.900 \mathrm{~m}$, não confirmada quantitativamente por falta de dados.

Em vertentes retilíneas e anfiteatros, a fração mineral dos solos é menos evoluída; os valores mínimos da soma caulinita-gibbsita ocorrem em setor retilineo de vertente convexa. Nos solos mais espessos, o horizonte subsuperficial pode apresentar menor quantidade de gibbsita e aumento das micas e de alguns minerais instáveis. As açðes erosivas fizeram aflorar as zonas mais profundas dos perfis e mesmo a rocha $\mathrm{sa}$. Feldspatos alteram-se em caulinita ou gibbsita. Soma caulinita-gibbsita inferior a $50 \%$, predominância de caulinita (Fig. 7), major frequência de minerais residuais, ausência de remobilização e reorganização do ferro, e apenas sinais incipientes de reorganizaçăo da gibbsita evidenciam um menor grau de evolução.

Nos anfiteatros, é característico o aumento das micas e a menor alteração das biotitas. Entretanto, nos anfiteatros relacionados aos morros de altitude superior a $1.800 \mathrm{~m}$, a rocha pode estar tão evoluida quanto no topo dos interflúvios - fato indicativo de maior profundidade de alteração. Nos depósitos, caulinita e micas såo os minerais mais importantes e a gibbsita predomina apenas acima dos $1.900 \mathrm{~m}$.
Nas planicies fluviais, ausência ou pequenas quantidades de gibbsita caracterizam a alteração da rocha sob os depósitos de terraço. Há caulinização ou dissoluçåo parcial dos feldspatos. A alteração das micas e do quartzo, a soma caulinita-gibbsita e os minerais residuais mostram um grau de intemperismo semelhante ao das vertentes incisas (Fig. 7).

Nos depósitos em rampa de colúvio, caulinita ou gibbsita predomina conforme a mineralogia dos materiais de origem. E típica a riqueza em micas e a maior ocorrência, em algumas camadas, de minerais residuais instáveis.

Em todos os compartimentos geomorfologicos, solos e rocha alterada estão altamente evoluídos e têm sua mineralogia representada essencialmente por quartzo, gibbsita e caulinita. A profundidade de alteração é grande e parece maior acima dos $1.800 \mathrm{~m}$. Rocha fresca aflora apenas em alguns setores incisos das vertentes.

As relações entre a compartimentação geomorfologica e grau de intemperismo são pouco nítidas nos solos e mais evidentes ao nivel da rocha alterada. $O$ horizonte subsuperficial dos solos mais espessos das vertentes apresenta-se, frequientemente, um pouco menos evoluido. Nas rochas, a variação do grau de intemperismo, nos diferentes compartimentos e em cada um deles, reflete a intensidade dos fenômenos erosivos; a alteraçâo é maior na borda e no topo dos interflúvios, com diminuição do grau de intemperismo pouco nítida no setor mamelonado e mais marcada nas áreas incisas das vertentes e sob os depósitos de terraço (Fig. 7).

As lateritas dos morros mais elevados representam o último estádio de evolução observado em toda a área. Apesar de os dados quantitativos não permitirem separá-las com segurança dos materiais de topo, a ausência de minerais residuais, além do quartzo, e fenômenos característicos de remobilizaçâo do ferro atestam sua maior evoluça.

Os resultados obtidos não permitem inferir relaçôes entre o grau de alteraçăo dos solos e a idade relativa dos 


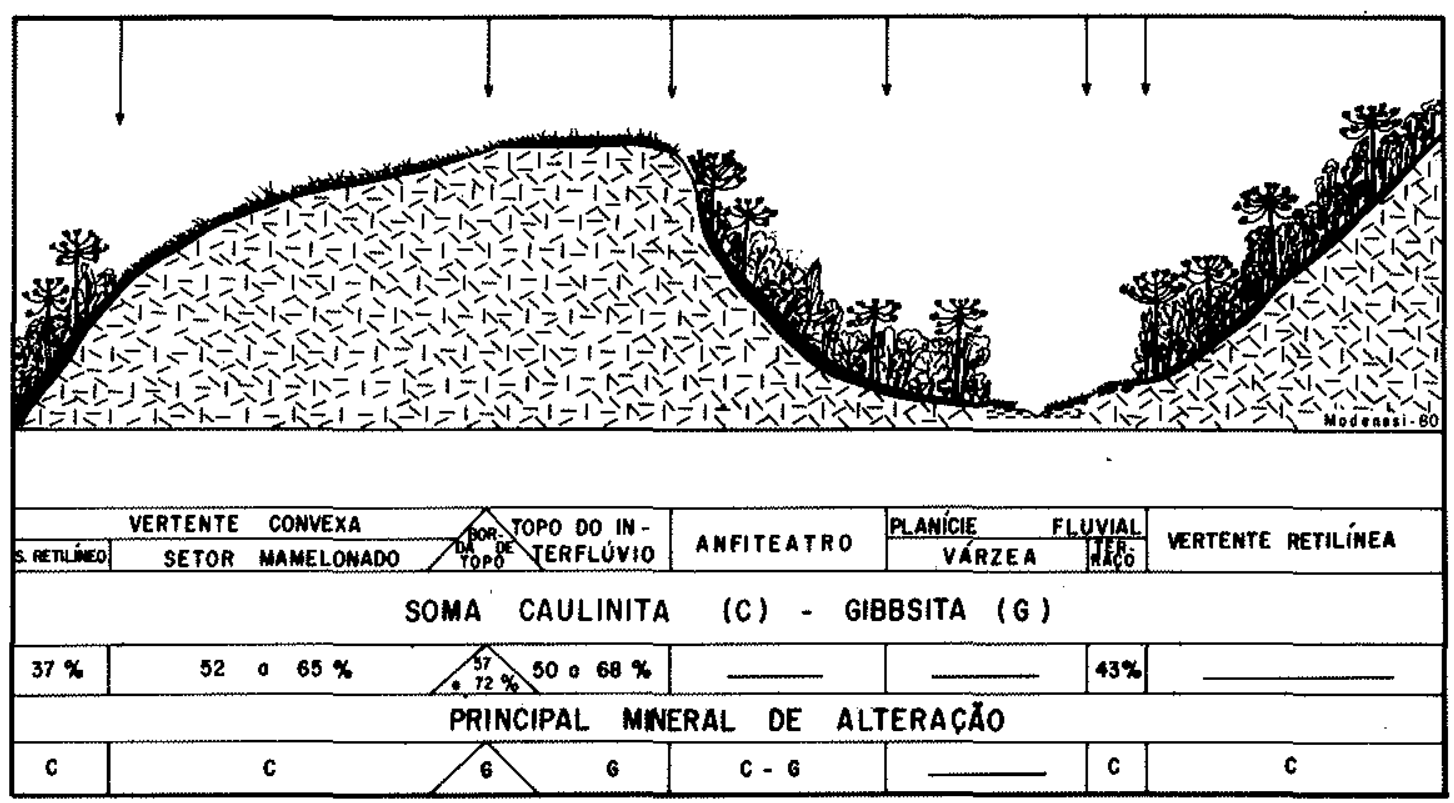

Figura 7 - Perfil esquemático das formas menores do relevo dos "altos campos". Correlaçðes com a alteração das rochas

niveis topográficos. Pode-se apenas esboçar uma separação entre solos situados acima e abaixo dos $1.800 \mathrm{~m}$. $\mathrm{Na}$ rocha alterada, a melhor conservaçåo das micas e a importância relativa da caulinita indicariam menor evolução da rocha nos dois níveis topográficos inferiores. Essa separação coincide com diferenças litológicas e pequenas variaçōes das condiçð̃es ambientais. Na borda do planalto, predominam rochas granitóides, temperaturas pouco mais baixas e precipitaçðes mais intensas que para o interior, onde a diminuição da altitude corresponde ao aparecimento dos migmatitos e a um relativo aumento da temperatura e diminuição da umidade.

A distribuição da vegetação de campo e mata nos vários compartimentos parece estreitamente ligada às características morfológicas e ao grau de intemperismo da rocha alterada e dos solos (Fig. 7).

A ALTERAÇÃO E SUAS IMPLICAÇŌES MORFOGENETICAS As relaçס̃es existentes entre grau e sequêencia de alteração dos depósitos e dos materiais de origem refletem, com frequencia, os processos responsáveis pela movimentaçåo dos materiais nas encostas. Esses fatos podem ser constatados nas rampas de colúvio e nos anfiteatros.

Nas rampas de colúvio, processos rasos de coluvionamento responsáveis pelo retrabalhamento dos materiais móveis, mais superficiais e alterados, pouco modificaram a mineralogia das formações superficiais. Sua alteraça reflete aquela dos materiais vertente acima $e o$ grau de alteraçăo é praticamente o mesmo. Seqưtências de alteração inversas ou desordenadas sugerem deposição sucessiva com superposição de camadas estratigráficas.

Nos anfiteatros, profundos movimentos de massa retrabalharam a parte superficial e também as zonas menos intemperizadas dos perfis, acarretando maior modificação das características mineralógicas. A relaçăo entre a alteração do depósito e das formações superficiais a montante é menor, e a renovaçào dos materiais é mais evidente. As sequências normais de alteração, encontradas nesses depósitos, correspondem à atuação de movi. mentos de massa capazes de transportar em conjunto todo o pacote alterado, com preservação da sequência original; em depósitos mais antigos podem corresponder à alteração pós-deposicional do regolito remanejado.

Gibbsitização intensa não corresponde necessariamente a estádio final de evolução. Teores elevados de gibbsitá podem ocorrer em rocha pouco alterada, ainda com residuos de feldspato (Fig. 3), fato que sugere processos de lixiviação intensa em tempo relativamente curto.

Apesar de não ser exclusiva, a gibbsitização é mais intensa e generalizada acima dos $1.900 \mathrm{~m}$ (Fig. 6), na borda do planalto, nos residuos da antiga superfície dos altos campos. A presumivel antiguidade da exposição, somada à predominância de rochas granitóides ricas em feldspato, à tendência à gibbsitização dos mesmos e às condiçőes de maior umidade e drenagem, poderia explicar a importância da gibbsita na rocha alterada. Nessas áreas, a caulinita é rara e só ocorre em alteração incipiente.

A caulinização coincide com os níveis topográficos mais baixos, onde predominam migmatitos e onde se observa uma tendência à caulinização das micas (Fig. 6). Entretanto um grande número de evidências em contrário nåo permite considerar a litologia como fator determinante da predominância de gibbsita ou caulinita nos materiais de alteração. Da mesma forma, a impor tância da caulinita no setor inferior das vertentes convexas e nos anfiteatros nåo pode ser atribuida apenas à relativa diminuição nas condiçōes de drenagem uma vez que essas áreas são também as mais dissecadas das vertentes. Só em posição de terraço, condiçðes de hidromorfia determinariam a preponderância, sem exceçðes, da caulinita. 
Caulinização corresponde sempre aos níveis topográficos mais recentes, às áreas mais instáveis da paisagem ou a uma menor alteração das rochas. O menor tempo de exposição às açőes do intemperismo parece ser o principal fator a determinar a ocorrência da caulinita na rocha alterada. Ao contrário, a gibbsitização ocorre, indiferentemente, sobre materiais muito ou pouco evoluídos, o que mostra a influência de outros fatores, além do tempo, na neogênese de gibbsita.

A distribuição espacial dos minerais secundários, com predominância de caulinita ou gibbsita em determinadas áreas do planalto, parece esboçar duas tendências de alteração (Fig. 6). Na borda do planalto, fenômenos de gibbsitização intensa permitem reconhecer uma tendência à alitização (Pedro, 1966), tanto nos materiais residuais da borda dos topos (lateritas aluminoferruginosas) e topo dos interflúvios, resultantes de uma alteração avançada atuante há longo tempo, como naqueles menos alterados das vertentes (bauxitas primárias), onde evidências de instabilidade dos materiais definem uma alteração recente. A gibbsitização é uma tendência recorrente.

Em altitudes inferiores a $1.800 \mathrm{~m}$, uma importância crescente da caulinita caracterizaria processos de sialitização, monossialitização (Pedro, 1966). Como foi exposto acima, esse tipo de alteração restringe-se às áreas menos intemperizadas.

Tais fatos parecem indicar que sialitização e alitização correspondem, na realidade, a diferentes graus de intemperismo numa área em que uma evolução relativamente rápida tende à alitização. $\mathrm{Na}$ borda do planalto, essa tendência teria sido acentuada por uma superposição de fatores favoráveis.

Certas características dos solos, encontradas especialmente na porção mais elevada do planalto, parecem indicar uma tendência à podzoliação, confirmada pelas observações de Oliveira et alii (1975) no Parque Estadual de Campos do Jordão. Essa tendência ocorre em equilíbrio com as condiçø̃es atuais de temperatura e umidade, favoráveis à redução do ferro e à formação de produtos orgânicos complexantes, capazes de provocar a migração do ferro típica da podzolização (Segalen, 1964).

Em perfis de vertente situados entre $1.700 \mathrm{e}$ $1.780 \mathrm{~m}$ aproximadamente, as características morfológicas sugerem, com freqüência, superposição da tendência podzolizante a outra mais antiga, ferralítica, impressa nos materiais vermelhos subjacentes. Esses materiais ferralíticos estariam associados a um meio de alteração diferente do atual, com boas condições de drenagem, oxidante em superfície e com decomposição muito rápida da matéria orgânica (Segalen, 1964; Maignien, 1966).

Nos perfis das formaçð̃es superficiais de vertentes é comum a superposição de cores vermelhas por outras amareladas. Como demonstraram vários autores (Segalen, 1964; Lamouroux, 1972; Lamouroux et alii, 1977; Volkoff e César, 1977; Volkoff, 1978; entre outros), essas cores associam-se à natureza dos produtos ferruginosos dos solos e os tons vermelhos ou amarelados correspondem, respectivamente, à predominância de hematita ou goethita.

Em Campos do Jordão, a passagem das cores vermelhas às bruno-amareladas, mais superficiais, é geral- mente abrupta nos depósitos e gradativa, sem descontinuidades, nos perfis de solo. A substituição gradual indicaria a transformação da hematita em goethita (Schwertmann, 1971), intimamente ligada a modificações do balanço da matéria orgânica nos solos e, por sua vez, a mudanças climáticas. Os materiais vermelhos, ricos em hematita, associar-se-iam a condições de alteração pretéritas. Os materiais bruno-amarelados refletem as condições atuais de temperatura e umidade, favoráveis a uma lenta evolução da matéria orgânica.

Nessas condições, a migração de ácidos orgânicos no perfil dissolve a hematita dos materiais vermelhos, por redução ou complexação do ferro, que pode reprecipitar em goethita. Uma hidrólise ácida ou acidólise provocaria a superimposição da goethita na parte superficial dos perfis (Schwertmann, 1971; Melfi et alii, 1979).

Essas considerações sobre a cor dos solos e a natureza dos compostos secundários de ferro, somadas às evidências morfológicas de superimposição de tendências pedogenéticas, sugerem mudanças das condiçð̄es ambientais e dos mecanismos evolutivos ligadas, provavelmente, a climas passados diferentes do atual. Os latossolos vermelhos e as lateritas testemunhariam climas mais quentes, úmidos ou subúmidos, nos quais o período chuvoso coincidia com temperaturas elevadas (Segalen, 1964; Maignien, 1966).

-A presença de gibbsita nos latossolos vermelhos permite associá-los a climas quentes com estações alternadas e vegetação de savanas, pois, segundo vários autores (D'Hoore, 1954; Fripiat et alii, 1954; Frankart et alii, 1960; Sys, 1965; Eswaran e Corninck, 1971; Siffermann, 1969, in Chatelin, 1972), essas condições favoreceriam a neogênese de gibbsita nos horizontes superiores de alteração.

A gibbsitização e os fenômenos de bauxitização em processo, observados nas rochas, não conflitam com o clima atual, mais fresco e úmido, uma vez que a formação de gibbsita se relaciona mais às condições locais de drenagem (facilitada por fraturas, clivagem dos minerais, juntas, etc.) que diretamente à temperatura e pluviosidade (Segalen, 1973). Além disso, como assinala Chatelin (1972), a neogênese de gibbsita no contato rocha-alterita seria favorecida em climas úmidos com chuvas regularmente distribuídas.

As ocorrências de restos de laterita e de latossolos vermelhos restringem-se, respectivamente, às altitudes superiores a $1.800 \mathrm{~m}$ e às vertentes do nível topográfico de 1.800-1.820 m. Essa posição topográfica e os longos períodos necessários a uma ferralitização da importância e generalização que os vestígios encontrados parecem sugerir permitiriam atribuir-lhes uma idade bastante antiga.

A provável aloctonia dos latossolos e as evidências de erosão intensa no topo dos interflúvios mais elevados (perfis com alteração incipiente da rocha) indicariam remanejamento e redistribuiçåo de materiais anteriormente alterados.

Lateritas e latossolos representariam os últimos vestígios de processos de alteração em climas quentes, úmidos ou mais provavelmente subúmidos, atuantes no Terciário. Esses materiais retrabalhados seriam evidências de processos de ferralitização anteriores, pelo menos, à acentuação pliocênica do soerguimento do pla- 
nalto, soerguimento este responsável pela modificação das características climáticas.

Tais observaçðes confirmariam as proposiçðes de Freitas (1951) e Almeida (1951, 1964) sobre a deformação da superfície do Japi e seu desdobramento tectônico em superficies das Cristas Médias e dos Campos, diferenciadas por De Martonne (1940) e consideradas por $A b$ 'Saber, em vários de seus trabalhos (entre eles, Ab'Saber e Bernardes, 1958), como superficies de erosão independentes.

\section{CONCLUSÕES GERAIS 1-As formaçס̃es super-} ficiais do Planalto de Campos do Jordão são caracterizadas, em sua maioria, por solos pouco espessos e alteração profunda das rochas. Rocha alterada, depósitos e solos constituem materiais muito intemperizados, com mineralogia representada quase exclusivamente por quartzo, gibbsita e caulinita; e argilo-minerais 2:1 (vermiculitas aluminosas) ocorrem em alteração incipiente de rochas granitóides e, principalmente abaixo dos $1.800 \mathrm{~m}$, no horizonte A de alguns solos.

2 - Nas áreas mais elevadas do planalto, feldspato e micas alteram-se em gibbsita; e fenômenos de bauxitização em processo ocorrem nas vertentes mamelonadas. A partir dos $1.800 \mathrm{~m}$, em direção aos níveis mais baixos, observa-se uma dicotomia de alteração com tendência à gibbsitização dos feldspatos e caulinização das micas, indiferentemente em granitoides e migmatitos.

3 - Nesses materiais altamente evoluidos, a importância da remobilização e reorganização do ferro na rocha alterada parece ser um criterio eficiente para diferenciar graus de intemperismo. A reorganizaçăo da gibbsita independe do grau de evoluçâo.

4 - Gibbsitização não corresponde, necessariamente, aos últimos estádios de evolução. A ocorrência de gibbsita na rocha alterada, independente do grau de intemperismo, define uma tendência geral à alitização, especialmente nítida acima dos $1.800 \mathrm{~m}$. Abaixo dessa altitude, o aumento de caulinita definiria a predominância de processos de monossialitização. Apesar de uma possível interferência litológica e ambiental na determinação dos dois tipos de alteração, estes parecem corres. ponder a diferentes graus de intemperismo dentro da mesma tendência geral.

5 - As relaçóes entre o grau de alteração das formaçðes superficiais e a compartimentação geomorfologica sâo mais perceptíveis ao nivel da rocha alterada que dos solos.

6 - Acima dos $1.800 \mathrm{~m}$ de altitude, as características de alteraçáo, principalmente da rocha alterada, definem as formaçóes superficiais da porção superior dos interflúvios como as mais intemperizadas. As lateritas aluminoferruginosas aí encontradas representam o último estádio de alteração das rochas.

7 - Nas vertentes, as diferenças do grau de intemperismo das rochas permitem distinguir uma cronologia de alteração relacionada à dinâmica morfogenética com diminuição do grau de intemperismo nos setores mais dissecados.

8 - Nos depósitos de vertente, em anfiteatros de erosão e rampas de colúvio, grau e sequência de alteração relacionam-se à morfodinâmica e não d̀ ação pédogenética pós-deposicional, ainda incipiente. Refletem, com certa frequêência, o tipo de processo responsável pela movimentação dos materiais nas encostas.

9 - A superposiçáo de cores, comum nas formaç̋es superficiais de vertente, corresponde à superposição de tendências pedogeoquímicas ligadas à variação das condiçøes ambientais. Os materiais vermelhos, muitas vezes latossolos retrabalhados, associam-se a condiçōes pretéritas favoráveis à ferralitização; e os amarelos no topo dos perfis, às condiçð̋es mais atuais de hidrólise ácida ou acidólise, responsáveis pela tendência podzolizante observada nos solos.

10 - A alitização é uma tendência de alteração recorrente, importante no passado (lateritas aluminoferruginosas) e no presente (bauxitas primárias). A ferralitização está ligada a condiçðes ambientais passadas.

11 - Lateritas e latossolos testemunhariam antiga fase de alteração ferralítica, em desacordo com as temperaturas relativamente baixas do clima de altitude vigente, pelo menos após a acentuação pliocênica do soerguimento do planalto. Essas ocorrências, nos altos campos do planalto, confirmariam o desdobramento tectônico da superfície do Japi, ou das Cristas Médias, permitindo correlacionar a superficie dos Campos a aplainamentos realizados em altitudes inferiores com posterior elevação aos níveis atuais.

12 - Características morfológicas e grau de intemperismo das formaçðes superficiais såo importantes fatores da organização do mosaico de vegetação típico dos altos campos do planalto. As matas instalam-se nos anfiteatros e nas áreas das vertentes onde os solos são mais profundos e o regolito incoerente permite a penetração das raizes, onde os solos e, principalmente, a rocha alterada ainda apresentam uma relativa reserva de minerais primários.

Agradecimentos Desejo expressar meus agradecimentos ao Doutor Jean-Marie Wackermann pela assistência contínua nas diversas etapas das análises mineralógicas. Ao Doutor Adolpho José Melfi, um agradecimento especial pelo apoio moral e técnico e pela leitura critica deste texto.

\section{BIBLIOGRAFIA}

AB'SABER, A.N. - $1966-0$ dominio morfoclimático dos mares de morros no Brasil. IGEOG-USP, Geomorfotogia (2): $9 \mathrm{pp}$.

AB'SABER, A.N. - 1969 - Um conceito de geomorfologia a servico das pesquisas sobre o Quaternário. IGEOG-USP, Geomorfologia (18): 23 pp.

AB'SABER, A.N. - 1970 - Provincias geologicas c dominios morfoclimáticos no Brasil. IGEOG-USP, Geomorfologia (20): 26 pp.

AB'SABER, A.N. - 1973 - A organizachlo das paisagens inter e subtropicais brasileiras. IGEOG-USP, Geomorfologia (41): 39 pp.
AB'SABER, A.N. e BERNARDES; N. - 1958 - Vale do Paralba, Serra da Mantiqueira e arredores de Sto Paulo. 18: Congr. Intern. Geogr. Guia de Excursoles (4): 303 pp., Rio de Janeiro.

ALMEIDA, F.F.M. de - 1951 - A propósito dos "relevos policiclicos" na tectônica do Escudo Brasilteiro. Bol. Paul. Geogr., 9: 3-18.

ALMEIDA, F.F.M. de - 1964 - Os fundamentos geologicos do relevo paulista. In Geologia do Estado de Sao Paulo. Secr. Agric. Estado SP, Inst. Geogr. Geol., Bol. (41): 167-263. 
ALMBIDA, F.F.M. de -1976 - The System of Continental Rifts bordering the Santos Basin, Brazil. In Continental Margins of Atlantic Type. Procee. Intern. Symp. on Contin. Margins of Atlantic Type, Săo Paulo, oct. 1975, Anais Acad. Bras. Ciênc. 48 (supl.): 15-26.

BIGARELLA, J.J. e MOUSINHO, M.R. - 1965 - Consideraços a respeito dos terraços fluviais, rampas de colúvio e várzeas. Bol. Paran. Geogr. (16-17): 153-197.

CHATELIN, Y, -1972 - Les sols ferrallitiques. Initiat.-Documents Téchn. ORSTOM, tome I (20).

COMISSAO NACIONAL DE SOLOS - 1960 - Levantamento de reconhecimento dos solos do Estado de Săo Paulo, Min, Agric. SNPA, Bol. (12): 634 pp.

DEWOLF, Y. - 1965 - Intérêt et principes d'une cartographie des formations superficielles. Assoc. Public. Fac. Lettres Sciences Humaines, Univ. Caen, 183 pp., Caen.

ERHART, H. - 1973 - linéraires Géochimiques el Cycle de l'Aluminium, 256 pp., Doin, Paris.

FREITAS, R.O. de - 1951 - Ensaio sobre a tectonica moderna do Brasil. Fac. Fil. Ciênc. Letras, USP, Bol (130), Geol. (6): $120 \mathrm{pp}$.

HARRISON, J.B, - 1933 - The Katamorphism of Igneous Rocks under $\mathrm{Hu}$ mid Tropical Conditions. Imperial Bur. Soil Scien., Rothamted Exp. Stn., 79 pp., Harpenden.

HASUI, Y, PONÇANO, W.L., ALMEIDA, M.A. e SANTOS, M.C.S.R. 1977 - Compartimentaçăo geomorfológica do Planalto Atlântico do leste paulista. Atas do I Simpósio de Geologia Regional, setembro de 1977, SBG, pp. 153-169.

INSTYTUTO DE PESQUISAS TECNOLOGICAS DO ESTADO DE SÃO PAULO S.A. - 1978 - Geologia da região administrativa 3 (Vale do Paraíba) e parte da regiăo administrativa 2 (Litoral) do Estado de Såo Paulo. Monografias (1), $78 \mathrm{pp}$. e mapa geológico.

LAMOUROUX, M. - 1972 - Etude des sols formés sur roches carbonatées: pedogénèse ferrallitique au Liban. Mémoires, ORSTOM, (56): $266 \mathrm{pp}$.

LAMOUROUX, M., LOYER, J.Y. e BOULEAU, A. - 1977 - Formes du fer des sols rouges et bruns fersiallitiques. Application de la Spectrométrie MOssbauer. Cahiers ORSTOM, Sér. Pédologie 5 (2): 199-210.

LELONG, F., TARDY, Y., GRANDIN, G., TRESCASES, J.J, e BOULANGE, B. - 1976 - Pedogenesis, Chemical Weathering and Processes of Formation of Some Supergene Ore Deposits. Reprinted from Handbook of Strata-bound and Stratiform Ore Deposits. K.H. Wolf (ed.), Elsevier Scient. Co., Cap. 3: 93-173, Amsterda.
MAIGNIEN, R. - 1966 - Review of Research on Laterites. Natural Resources Research UNESCO 4: 148 pp., Liège.

MARTONNE, E. de - 1940 - Problèmes morphologiques du Brésil Tropical Atlantique, Ann. Géogr, 49 (277): 1-27 e (278-279): 106-129. Traducto Rev. Bras. Geogr. 5 (4): 523-550 e 6 (2): 155-178, 1943/1944.

MELFI, A.J. e PEDRO, G. - 1977 - Estudo geoquímico dos solos e formaçoes superficiais do Brasil. Parte I - Caracterizaçăo e repartiçáo dos principais tipos de evoluçấo pedogeoquímica. Rev. Bras. Geoc. 7 (4): 271-286.

MELFI, A.J., PEDRO, G. e VOLKOFF, B. - 1979 - Natureza e distribuiçăo dos compostos ferriferos nos solos do Brasil. Rev. Bras. Ciênc. Solo 3 (1): 47 54.

MODENESI, M.C. - 1974 - Contribuiçăo à Geomorfologia da Regiâo de ItuSalto: estudo de formaçðes superficiais. IGEOG-USP, Ser. Teses e Monogr. (10): 99 pp.

OLIVEIRA, J.B., MENK, J.R.F. e ROTTA, C.C. - 1975 - Solos do Parque Estadual de Campos do Jordao. Silvicultura em Săo Paulo. Rev. Inst. Florestal da Secr. Agric. Estado SP, Coord. Pesq. Rec. Nat. 9: 125-155.

PEDRO, G. - 1966 - Essai sur la caractérization géochimique des differents processus zonaux de l'altération superficielle des roches. Compt. Rend. Acad. Scien. Paris (292-D): 1828-1831.

ROBERT, M. - 1975 - Principes de determination qualitative des minéraux argileux a l'aide des Rayons X. Ann. Agronom. 26 (4): 363-399.

SCHWERTMANN, U. - 1971 - Transformation of Hematite to Goethite in Solls. Nature 232: 624-625.

SEGALEN, P. - 1964 - Le fer dans les sols. Init.-Docum. Téchn., ORSTOM $150 \mathrm{pp}$.

SEGALEN, P. - 1973 - L'aluminium dans les sols. Init,-Docum. Techn. ORSTOM (22), $23 \mathrm{pp}$.

TRICART, J. - 1965 - Principes et Methodes de la Géomorphologie. Masson et Cie. Edit., $496 \mathrm{pp}$., Paris.

VOLKOFF, B. - 1978 - Os produtos ferruginosos que determinam a cor dos latossolos da Bahia. Rev. Bras, Cienc. Solo 2 (1): 55-59.

VOLKOFF, B. e CESAR, U.R.S. - 1977 - Ferro nos latossolos do Estado da Bahia. Rev. Bras. Cienc. Solo $1(2 / 3)$; $85-92$.

WACKERMANN, J.M. e MODENESI, M.C. - 1980 - Seqüência de alteraçăo em rochas cristalinas ácidas sob clima tropical de altitude no planaito de Campos do Jordåo - Estado de Săo Paulo (inédito). 